\title{
Investigating the Impact of Computer Technology
}

\section{On the Teaching and Learning of Graphic Arts}

\section{In Nigeria Osun State College of Education Ila-orangun as a Case Study}

\author{
Bada Tayo Abass \\ Faculty of Education, Obafemi Awolowo University \\ Ile - Ife, Osun State, Nigeria \\ E-mail: badatayo2@yahoo.com
}

Received: February 21, 2012

Accepted: March 7, 2012

Published: June 15, 2012

doi:10.5430/wje.v2n3p71

URL: http://dx.doi.org/10.5430/wje.v2n3p71

\begin{abstract}
This paper focused on the use of computer technology in the teaching and learning of graphic arts in Nigeria colleges of Education. Osun State Colleges of Education Ila- Orangun was used as a case study. The population of the study consisted of all Graphic students in Nigeria colleges of Education. 50 subjects were used for the study while questionnaires were used to gather data. The data collected were analyzed using simple percentages. The results of the analyzed data revealed that computer technology enhanced the teaching and learning of Graphic arts. The study concluded that computer would contribute immensely to the teaching and learning of graphic arts in schools.
\end{abstract}

Keywords: Graphics, Softwares, Technology, Art, Hieroglyphics, Aesthetics

\section{Introduction}

The roles of computer technology in enhancing teaching and learning cannot be overmphasized (Vijendra Lal, 2002).Studies have shown that while there are benefits of using such technology there has not been many rigorous and systematic studies that have investigated its impact on teaching and learning (Bennett \& Lockyer, 1999), (Harper, et.al, 2000).According to them, this is due to a number of factors which include a lack of resources and expertise in schools to do research including a culture in schools which does not encourage research, the vast amount of time taken up in technologyimplementations and the embryonic nature of this field which is still developing and undergoing constant change (McKenzie, 1995), (Bennett and Lockyer, 1999). A number of investigations have been conducted to understand teachers'perceptions of omputer-based technologies. Balli et al (1997) investigated pre-service teachers' reactions to technology available in schools and its use by students. They found that many of these teachers were surprised by the sophisticated nature of what was available in schools and the students' abilities in using them. This led many of them to reassess their perceptions and it also helped increase their confidence levels in using these technologies. Some studies have noted how teachers' perceptions and practices have changed as they move from a position of anxiety to increasing comfort (CELT report, 1995) (Bernauer, 1996). Heflich, 1996 identified that those from high access schools had more positive perceptions about computers ability to increase access to information and enhance communication than their colleagues in low access schools who tended to be concerned more about the ability of their students in managing large amounts of information. A number of studies have explored the impact of computer-based technologies on learning outcomes and reported on some improvements to student learning outcomes.Denton and Manus (1995) who analysed standardised test scores of students from 8 schools using computer technologies found that only some schools showed improvements but this was not evident in all subject areas. Follansbee et al (1996) found that students with online access produced better projects in terms of presentation, integration of different perspectives and presentation of a full picture. Chessler et al (1998) found that teachers reported a higher quality of work from students who used laptops than those who didn't. Tierney et al (1996) found that over time students who use computers begin to explore and express ideas in fairly sophisticated ways using graphical and other non-linear orms. Williams (1999) found that sixth graders who worked in a hyper media supported context were able to solve problems more effectively than those who didn't. Richards (1996) who surveyed teachers found that they reported on improvements in their students reading, writing and team skills as a result of using computers. A number of studies have focused on the impact of computer technologies on 
the learning environment of classrooms including the learning activities which take place in the classroom, and the teaching and learning strategies used to facilitate them. Kaye (1995) found that students in a networked learning environment are able to do discovery-based, student centred learning through a range of individualised and collaborative activities. Follansbee et al (1996) found those students with computers and online access tended to gather, organise and present information in multimedia formats for tasks that related to a project-based unit of study. Bernauer (1996) in his investigation reported on students producing their own hypermedia software with the introduction of computers at his school. Sandholtz et al (1997) reports on students using computers to collaboratively construct web based virtual environments.

Wiesenmayer and Koul (1998) reported on how the internet was used in hands-on, project- based activities, including collaboration both within and outside the classroom. Bernauer (1996) noted another impact of computer-based technologies in the classroom learning environment. This related to the need for different timetable arrangements and the need for longer class periods to accommodate project based work with computers. As a result of the poor method of teaching, students see graphic art as difficult, hence they develop negative attitude towards it. Bada and Fadare 2002). Wender and Muelboeck (2003) are of the opinion that for a long time, traditional teaching has relied on drawings and illustrations in order to enhanceunderstanding and retention of abstract concepts. Adekomi (2006) however opined that computer would enhance teaching and learning of graphic arts.

\subsection{Purpose of the Study}

The purpose of this study is to investigate the effect of computer technology on the teaching and learning of Graphic Arts in Nigeria Colleges of Education.

\subsection{Research Questions}

The following research questions were generated for this study:

(i) Is there any significant effect of Computer Technology on the teaching of Graphics in schools?

(ii) Will there be relationship between Computer Technology and teaching of graphics arts?

\subsection{Research Method}

This study employed survey research method.

\subsection{Population}

The population of the study consisted of all Graphic students in all Nigerian Colleges of Education.

\subsection{Research sampling}

The sample consisted of 50 participants which were radomly selected from the Department of Fine and Applied Arts, Oaun State College of Education, Ila Orangun.

\subsection{Research Method}

The instrument used for the collection of data is a structured questionnaire. The questionnaire was designed to contain both open and close ended questions.

\subsection{Data Collection Technique}

Data were collected from 50 participants through the use of structured questionnaire.

\subsection{Data Analysis Technique}

Data collected through the questionnaires were analyzed and interpreted with the use of tables and percentages.

\subsection{Results and Discussion of Findings}

The data analyzed here were obtained from the view of 50 respondents who responded to the questionnaire. This analysis was done through the use of simple descriptive statistical tool that is, percentage to indicate the difference in opinions.

\section{Do you know what a computer is?}

$<$ Table 1 about here>

The above Table 1 shows that $98 \%$ of the respondents know what a computer is and $2 \%$ does not. 


\section{Do you know what a computer does?}

<Table 2 about here>

The Table 2 above indicates that $94 \%$ of the respondents know what a computer does and $6 \%$ of the total respondents do not know.

\section{Do you have a computer or laptop?}

$<$ Table 3 about here>

The above Table 3 shows that $70 \%$ of the respondents do have a personal computer system or a laptop, while $30 \%$ of them do not have a personal laptop or computer system.

Do you make use of a computer often?

<Table 4 about here>

The Table 4 above indicates that $84 \%$ of the respondents make use of the computer often and $16 \%$ of the total respondents do not.

\section{Do you know what graphic arts is?}

<Table 5 about here>

The above Table 5 shows that $96 \%$ of the respondents do know what graphics arts means, while $4 \%$ of them do not what it means.

\section{Do you know that computer aids graphic arts?}

<Table 6 about here>

The above Table 6 indicates that all the respondents know that the computer aids graphic arts.

\section{Graphic arts is a self reliance career.}

\section{<Table 7 about here>}

The above Table 7 reveals that $96 \%$ of the respondents agree to the fact that graphics art is a self reliance career, $4 \%$ are not sure if it is and none of the respondents disagree completely that graphics art is not.

\section{Does Computer Technology add aesthetic appreciation, pleasure and perfection to graphic works?}

<Table 8 about here>

The Table 8 above indicates that $92 \%$ of the respondents agree to the fact that Computer technology adds aesthetic appreciation, pleasure and perfection to graphic works, while $8 \%$ are not sure if it does and none of the respondents disagree completely that Computer technology does that.

\section{Different software are used to aid graphic arts teaching.}

<Table 9 about here>

The above Table 9 shows that $96 \%$ of the respondents agree that different software are used to aid graphic arts teaching, and $4 \%$ are not sure if it is so and none of the respondents disagree completely that it is not so.

\section{Computer software exposes both the teacher and students to the vast usage of computer.}

$<$ Table 10 about here>

The above Table 10 shows that $88 \%$ of the respondents agree that Computer software exposes both teachers and students to the vast usage of computer, and $8 \%$ are not sure if it does while $4 \%$ of the respondents disagree completely that Computer software does not expose teachers and students the vast usage of computer. 
Graphic art is interesting when teaching using the computer oriented software.

<Table 11 about here>

The Table 11 above indicates that $98 \%$ of the respondents believe that graphics art is interesting when teaching using the computer oriented software, while $2 \%$ of the respondents do not agree.

\section{Has computer technology helped to develop students' creative skills and students learning faster?}

\section{$<$ Table 12 about here>}

Table 12 indicates that $100 \%$ that is, all the respondents' agree that computer technology helps to develop students creative skills and abilities and makes students learn faster.

\section{Does computer technology assist the teachers simplify their teaching methods?}

<Table 13 about here>

The Table 13 above indicates that $96 \%$ of the respondents believe that computer technology assists the teachers to simplify their teaching methods, while $4 \%$ of the respondents do not agree with that fact.

\section{Have you ever designed any graphics work with the computer?}

$<$ Table 14 about here>

The Table 14 above shows that $84 \%$ of the respondents have at a point in time designed a graphics work with the computer while $16 \%$ of the respondents have never attempted to design any graphic work.

\section{Have you explored several other softwares used in graphic arts teaching?}

$<$ Table 15 about here>

The Table 15 above indicates that $84 \%$ of the respondents have explored several other softwares used in graphic arts teaching, while $20 \%$ of the respondents have not.

\section{Do you believe that computer actually aided the teaching and learning of graphic arts?}

$<$ Table 16 about here>

Table 16 shows that $100 \%$ that is, all the respondents do believe that computer actually aided the teaching and learning of graphic arts.

\section{Does computer usage prompt my interest and zeal for graphics?}

\section{$<$ Table 17 about here>}

Table 17 above reveals that $92 \%$ of the respondents agree to the fact that computer usage prompted their interest and zeal for graphics, while $8 \%$ of the respondents disagree with that fact.

\section{Conclusion}

The study concluded that computer enhances the three domains of educating an individual that is, the cognitive, affective and psycho-motor. It will enhance the teaching of graphics and the discovery of updated softwares that can be used in executing a graphical design. In view of this, it is established that the teaching and learning of graphic arts will be enhanced if computer is effectively utilized. 


\section{Recommendations}

The schools should provide an environment wherein students will be interested in learning computer, education policy makers should incorporate the numberless benefits of recent research concerning the effect of computer on graphic arts teaching and learning. Finally, International conferences and workshops should be organized for teachers in order to have a wider and broader knowledge about the full exploration of computer technology and its benefits on teaching and learning of graphics.

\section{References}

Adekomi,B.(2006).Computer and learning.Ondo. Trinity Press.

Bada, T. \& Fadare O. (2002).Graphic arts.Ilesa.Onibonoje Press.

Balli, S. J., Wright, M. D. \& Foster, P. N. (1997) Preservice teachers' field experiences with technology. Educational Technology. 37(5): 40-46.

Bennett \& Lockyer (1999) The Impact of Digital Technologies on Teaching and Learning in K-12 Education. Report prepared for the Curriculum Corporation, (Available URL: http://socci.edna.edu.au/content/pdf/lit_res.pdf)

Bernauer, J. A. (1996) Technology and leadership. Paper presented at the Annual Meeting of the American Educational Research Association (New York, NY, April 8-12, 1996) (Eric document ED394503). Centre for Educational Leadership and Technology (CELT) (1995) America's 21st century school: linking education reform and technology. Marlborough, MA (Eric document ED393396).

Chessler, M., Rockman, S., and Walker, L. (1998) Powerful tools for schooling: second year study of the laptop program. San Francisco: Rockman ET AL.

Follansbee, S., Gilsdorf, N., Stahl, S., Dunfey, J., Cohen, S., Pisha, B. \& Hughes, B. (1996) The role of online communication in schools: a national study. Peabody, MA: Center for Applied Special Technology.

Harper, et.al (2000) Review of Research: the on-line experience: the state of Australian on-line education and training practices. Report prepared for NCVER

Heflich, D. A. (1996) The impact of online technology on teaching and learning: attitudes and ideas of educators in the field. Paper presented at the Annual Meeting of the Mid-South Educational Research Association (25th, Tuscaloosa, AL, November 6-8, 1996).

Kaye, J. C. (1996) Characteristics of effective networking environments. Paper presented at the Annual Meeting of the American Educational Research Association, New York, NY, April 8-12, 1996. (Eric document ED394502).

McKenzie, J. (1995) "Did anybody learn anything?" Assessing technology programs and the learning accomplished. From Now On. 5(4). [Available URL: http://fromnowon.org/Dec95/simpletext.html].

Richards, F. C. (1996) The impact of the Internet on teaching and learning as perceived by teachers, library media specialists and students. Unpublished Masters thesis. Salem-Teikyo University. (Eric document ED410943).

Tierney, R. J., Kieffer, R., Stowell, L., Desai, L. E. \& Whalin, K. (1992) Computer acquisition: a longitudinal study of the influence of high computer access on students' thinking, learning, and interactions. ACOT Report \#16. Cupertino, CA: Apple Computer.

Sandholtz, J. H., Ringstaff, C. \& Dwyer, D. C. (1997) Teaching with technology: creating student-centred classrooms. New York: Teachers College Press.

Vijendra, L. (2002). The impact of computer-based technologies in Schools - literature review (VL 10/02)

Wiesenmayer, R. \& Koul, R. (1998) Integrating Internet resources into the science classroom: Teachers' perspectives. Journal of Science Education and Technology. 7(3), 271-277. http://dx.doi.org/10.1023/A:1021848608930 
Table 1. Do you know what a computer is?

\begin{tabular}{|l|c|c|c|c|}
\hline & Frequency & Percent & Valid Percent & Cumulative Percent \\
\hline Yes & 49 & 98.0 & 98.0 & 98.0 \\
\hline No & 1 & 2.0 & 2.0 & 100.0 \\
\hline Total & 50 & 100.0 & 100.0 & \\
\hline
\end{tabular}

Table 2. Do you know what a computer does?

\begin{tabular}{|l|c|c|c|c|}
\hline & Frequency & Percent & Valid Percent & Cumulative Percent \\
\hline Yes & 47 & 94.0 & 94.0 & 94.0 \\
\hline No & 3 & 6.0 & 6.0 & 100.0 \\
\hline Total & 50 & 100.0 & 100.0 & \\
\hline
\end{tabular}

Table 3. Do you have a computer or laptop?

\begin{tabular}{|l|c|c|c|c|}
\hline & Frequency & Percent & Valid Percent & Cumulative Percent \\
\hline Yes & 35 & 70.0 & 70.0 & 70.0 \\
\hline No & 15 & 30.0 & 30.0 & 100.0 \\
\hline Total & 50 & 100.0 & 100.0 & \\
\hline
\end{tabular}

Table 4. Do you make use of a computer often?

\begin{tabular}{|l|c|c|c|c|}
\hline & Frequency & Percent & Valid Percent & Cumulative Percent \\
\hline Yes & 42 & 84.0 & 84.0 & 84.0 \\
\hline No & 8 & 16.0 & 16.0 & 100.0 \\
\hline Total & 50 & 100.0 & 100.0 & \\
\hline
\end{tabular}


Table 5. Do you know what graphic arts is?

\begin{tabular}{|l|c|c|c|c|}
\hline & Frequency & Percent & Valid Percent & Cumulative Percent \\
\hline Yes & 48 & 96.0 & 96.0 & 96.0 \\
\hline No & 2 & 4.0 & 4.0 & 100.0 \\
\hline Total & 50 & 100.0 & 100.0 & \\
\hline
\end{tabular}

Table 6. Do you know that computer aids graphic arts?

\begin{tabular}{|c|c|c|c|c|}
\hline & Frequency & Percent & Valid Percent & Cumulative Percent \\
\hline Yes & 50 & 100.0 & 100.0 & 100.0 \\
\hline
\end{tabular}

Table 7. Graphic arts is a self reliance career.

\begin{tabular}{|l|c|c|c|c|}
\hline & Frequency & Percent & Valid Percent & Cumulative Percent \\
\hline Agree & 48 & 96.0 & 96.0 & 96.0 \\
\hline Not sure & 2 & 4.0 & 4.0 & 100.0 \\
\hline Total & 50 & 100.0 & 100.0 & \\
\hline
\end{tabular}

Table 8. Does Computer Technology add aesthetic appreciation, pleasure and perfection to graphic works?

\begin{tabular}{|l|c|c|c|c|}
\hline & Frequency & Percent & Valid Percent & Cumulative Percent \\
\hline Agree & 46 & 92.0 & 92.0 & 92.0 \\
\hline Not sure & 4 & 8.0 & 8.0 & 100.0 \\
\hline Total & 50 & 100.0 & 100.0 & \\
\hline
\end{tabular}

Table 9. Different software are used to aid graphic arts teaching.

\begin{tabular}{|l|c|c|c|c|}
\hline & Frequency & Percent & Valid Percent & Cumulative Percent \\
\hline Agree & 48 & 96.0 & 96.0 & 96.0 \\
\hline Not sure & 2 & 4.0 & 4.0 & 100.0 \\
\hline Total & 50 & 100.0 & 100.0 & \\
\hline
\end{tabular}


Table 10. Computer software exposes both the teacher and students to the vast usage of computer.

\begin{tabular}{|l|c|c|c|c|}
\hline & Frequency & Percent & Valid Percent & Cumulative Percent \\
\hline Agree & 44 & 88.0 & 88.0 & 88.0 \\
\hline Not sure & 4 & 8.0 & 8.0 & 96.0 \\
\hline Disagree & 2 & 4.0 & 4.0 & 100.0 \\
\hline Total & 50 & 100.0 & 100.0 & \\
\hline
\end{tabular}

Table 11. Graphic art is interesting when teaching using the computer oriented software.

\begin{tabular}{|l|c|c|c|c|}
\hline & Frequency & Percent & Valid Percent & Cumulative Percent \\
\hline Yes & 49 & 98.0 & 98.0 & 98.0 \\
\hline No & 1 & 2.0 & 2.0 & 100.0 \\
\hline Total & 50 & 100.0 & 100.0 & \\
\hline
\end{tabular}

Table 12. Has computer technology helped to develop students' creative skills and students learning faster?

\begin{tabular}{|c|c|c|c|c|}
\hline & Frequency & Percent & Valid Percent & Cumulative Percent \\
\hline Yes & 50 & 100.0 & 100.0 & 100.0 \\
\hline
\end{tabular}

Table 13. Does computer technology assist the teachers simplify their teaching methods?

\begin{tabular}{|l|c|c|c|c|}
\hline & Frequency & Percent & Valid Percent & Cumulative Percent \\
\hline Yes & 48 & 96.0 & 96.0 & 96.0 \\
\hline No & 2 & 4.0 & 4.0 & 100.0 \\
\hline Total & 50 & 100.0 & 100.0 & \\
\hline
\end{tabular}

Table 14. Have you ever designed any graphics work with the computer?

\begin{tabular}{|l|c|c|c|c|}
\hline & Frequency & Percent & Valid Percent & Cumulative Percent \\
\hline Yes & 42 & 84.0 & 84.0 & 84.0 \\
\hline No & 8 & 16.0 & 16.0 & 100.0 \\
\hline Total & 50 & 100.0 & 100.0 & \\
\hline
\end{tabular}


Table 15. Have you explored several other softwares used in graphic arts teaching?

\begin{tabular}{|l|c|c|c|c|}
\hline & Frequency & Percent & Valid Percent & Cumulative Percent \\
\hline Yes & 40 & 80.0 & 80.0 & 80.0 \\
\hline No & 10 & 20.0 & 20.0 & 100.0 \\
\hline Total & 50 & 100.0 & 100.0 & \\
\hline
\end{tabular}

Table 16. Do you believe that computer actually aided the teaching and learning of graphic arts?

\begin{tabular}{|c|c|c|c|c|}
\hline & Frequency & Percent & Valid Percent & Cumulative Percent \\
\hline Yes & 50 & 100.0 & 100.0 & 100.0 \\
\hline
\end{tabular}

Table 17. Does computer usage prompt my interest and zeal for graphics?

\begin{tabular}{|l|c|c|c|c|}
\hline & Frequency & Percent & Valid Percent & Cumulative Percent \\
\hline Yes & 46 & 92.0 & 92.0 & 92.0 \\
\hline No & 4 & 8.0 & 8.0 & 100.0 \\
\hline Total & 50 & 100.0 & 100.0 & \\
\hline
\end{tabular}

